4 Laurin C, Lavoie KL, Bacon SL, et al. Sex differences in the prevalence of psychiatric disorders and psychological distress in patients with COPD. Chest 2007; 132: 148-155.

5 Brenes GA. Anxiety and chronic obstructive pulmonary disease: prevalence, impact, and treatment. Psychosom Med 2003; 65: 963-970.
6 Wamboldt F. Anxiety and depression in COPD: a call (and need) for further research. COPD 2005; 2: 233-241.

DOI: $10.1183 / 09031936.00079808$

\title{
Inhibition of the renin-angiotensin system in severe COPD
}

\section{To the Editors:}

In a recent issue of the European Respiratory Journal, ALBERT and CALVERLEY [1] analysed the treatment approaches in severe chronic obstructive pulmonary disease (COPD). However, they did not mention the effect of the inhibition of the reninangiotensin system (RAS) in this setting.

Angiotensin converting enzyme (ACE) is present in very high concentrations in the lungs, and its activity is further increased by chronic hypoxia $[2,3]$. Indeed, in patients with COPD, lower ACE activity may improve the efficiency of the peripheral use of oxygen and respiratory muscle function $[3,4]$.

Furthermore, mounting evidence suggests that COPD is characterised by systemic inflammation that might have an adverse impact on various extrapulmonary organs [5]. Interestingly, RAS blockade exerts an anti-inflammatory action in many systems [6].

Finally, even some side-effects related to therapy with inhibitors of the RAS, in certain instances, can prove beneficial in some patients with COPD. An intact and activated RAS has been shown to be an important determinant of erythropoiesis [7], and it has been found that the inhibition of the RAS may be a useful treatment for secondary erythrocytosis [8, 9]. Consequently, RAS blockade might have profound benefits in the long-term treatment of COPD-associated polycythaemia. Moreover, even cough, a well-characterised side-effect of ACE inhibitors, could be of some benefit in that it can decrease the risk of aspiration pneumonia in certain patient settings [10].

Therefore, we suggest that future studies should assess the overall health impact of renin-angiotensin system blockade in patients with chronic obstructive pulmonary disease.

\section{Mascitelli*, F. Pezzetta" and M.R. Goldstein "}

*Medical Service, Comando Brigata alpina "Julia", Udine, and "Cardiology Service, Ospedale di Tolmezzo, Tolmezzo, Italy.

${ }^{\top}$ Fountain Medical Court, Bonita Springs, FL, USA.

STATEMENT OF INTEREST

None declared.

\section{REFERENCES}

1 Albert P, Calverley PMA. Drugs (including oxygen) in severe COPD. Eur Respir J 2008; 31: 1114-1124.

2 Nong Z, Stassen JM, Moons L, Collen D, Janssens S. Inhibition of tissue angiotensin-converting enzyme with quinapril reduces hypoxic pulmonary hypertension and pulmonary vascular remodeling. Circulation 1996; 94: 1941-1947.

3 Kanazawa H, Okamoto T, Hirata K, Yoshikawa J. Deletion polymorphisms in the angiotensin converting enzyme gene are associated with pulmonary hypertension evoked by exercise challenge in patients with chronic obstructive pulmonary disease. Am J Respir Crit Care Med 2000; 162: 1235-1238.

4 Kanazawa H, Hirata K, Yashikawa J. Effects of captopril administration on pulmonary hemodynamics and tissue oxygenation during exercise in ACE gene subtypes in COPD patients: a preliminary study. Thorax 2003; 58: 629-631.

5 Cazzola M, Matera MG, Rogliani P, Page C. Treating systemic effects of COPD. Trends Pharmacol Sci 2007; 28: 544-550.

6 Dandona P, Dhindsa S, Ghanim H, Chaudhuri A. Angiotensin II and inflammation: the effect of angiotensinconverting enzyme inhibition and angiotensin II receptor blockade. J Hum Hypertens 2007; 21: 20-27.

7 Mrug M, Stoppa T, Julian BA, Prchal JF, Prchal JT. Angiotensin II stimulates proliferation of normal early erythroid progenitors. J Clin Invest 1997; 100: 2310-2314.

8 Julian BA, Brantley RR Jr, Barker CV, et al. Losartan, an angiotensin II type 1 receptor antagonist, lowers hematocrit in posttransplant erythrocytosis. J Am Soc Nephrol 1998; 9: 1104-1108.

9 Plata R, Cornejo A, Arratia C, et al. Angiotensinconverting-enzyme inhibition therapy in altitude polycythaemia: a prospective randomised trial. Lancet 2002; 359: 663-666.

10 Rafailidis PI, Matthaiou DK, Varbobitis I, Falagas ME. Use of ACE inhibitors and risk of community-acquired pneumonia: a review. Eur J Clin Pharmacol 2008; 64: 565-573. 